\title{
Kytococcus aerolatus sp. nov., isolated from indoor air in a room colonized with moulds
}

\author{
P. Kämpfer ${ }^{\mathrm{a}, *}$, K. Martin ${ }^{\mathrm{b}}$, J. Schäfer ${ }^{\mathrm{a}}$, P. Schumann ${ }^{\mathrm{c}}$ \\ ${ }^{a}$ Institut für Angewandte Mikrobiologie, Justus-Liebig-Universität Giessen, Heinrich-Buff-Ring 26-32, D-35392 Giessen, Germany \\ ${ }^{\mathrm{b}}$ Leibniz-Institut für Naturstoff-Forschung und Infektionsbiologie e. V., Hans-Knöll-Institut, D-07745 Jena, Germany \\ ${ }^{c} D S M Z$ - Deutsche Sammlung von Mikroorganismen und Zellkulturen GmbH, Inhoffenstraße 7b, D-38124 Braunschweig, Germany
}

\begin{abstract}
A Gram-positive, coccoid bacterial isolate $\left(02-\mathrm{St}-019 / 1^{\mathrm{T}}\right)$, forming beige pigmented colonies was obtained from an indoor air sample. Based on $16 \mathrm{~S}$ rRNA gene sequence similarity studies it was determined that this isolate $02-\mathrm{St}-019 / 1^{\mathrm{T}}$ belonged to the genus Kytococcus, showing sequence similarties of $98.6 \%$ to Kytococcus schroeteri DSM $13884^{\mathrm{T}}$ and $98.3 \%$ to Kytococcus sedentarius DSM $20547^{\mathrm{T}}$, respectively. The diagnostic diaminoacid of the peptidoglycan was lysine, cell wall sugars were ribose and xylose. The major menaquinones detected were MK-7 and MK-8. The polar lipid profile consisted of the major phospholipids diphosphatidylglycerol, phosphatidylglycerol, phosphatidylinositol, phosphatidylserine and phosphatidylinositol mannoside. Fatty acid patterns were composed of major amounts of the iso- and anteiso-branched fatty acids anteiso $C_{17: 0}$, iso $C_{15: 0}$ and iso $C_{17: 0}$ and unsaturated fatty acids $\left(C_{17: 1} \omega 8 \mathrm{c}\right.$, iso $C_{17: 1} \omega 9 \mathrm{c}$, and $\left.C_{17: 1} \omega 8 \mathrm{c}\right)$ with smaller amounts of the straight-chain fatty acids $\mathrm{C}_{15: 0}, \mathrm{C}_{16: 0}$ and $\mathrm{C}_{17: 0}$. The results of DNA-DNA hybridizations and physiological and biochemical tests clearly allowed a genotypic and phenotypic differentiation of strain $02-\mathrm{St}-019 / 1^{\mathrm{T}}$ from the two described Kytococcus species. On the basis of these results a novel species to be named Kytococcus aerolatus sp. nov., is proposed, with the type strain $02-\mathrm{St}-019 / 1^{\mathrm{T}}(=\mathrm{DSM}$ $22179^{\mathrm{T}}=\operatorname{CCM} 7639^{\mathrm{T}}$.
\end{abstract}

The genus Kytococcus, described by Stackebrandt et al. [18] comprises at present only the two species Kytococcus sedentarius [18] and Kytococcus schroeteri [1]. The genus forms a separate lineage in the $16 \mathrm{~S}$ rRNA sequence based tree and can also be differentiated from

\footnotetext{
The EMBL accession number for the 16S rRNA gene sequence of strain $02-$ St-019/1 ${ }^{\mathrm{T}}$ is FM 992368 .

${ }^{*}$ Corresponding author. Tel. +496419937352 ;

fax: +496419937359 .

E-mail address: peter.kaempfer@umwelt.uni-giessen.de

(P. Kämpfer).
}

the most closely related genera by chemotaxonomic properties [18]. Strain 02-St-019/1 ${ }^{\mathrm{T}}$ was enriched and recovered from the air in a room with walls colonized with moulds. Microorganisms were collected by filtration of 1001 of air through a gelatine filter. This filter was placed on an agar plate containing ISP-3 medium [16] and incubated at $28^{\circ} \mathrm{C}$. After 2 weeks the strain $02-\mathrm{St}-019 / 1$ was isolated from the plate and maintained on medium 79 [11].

Morphological properties, Gram-staining and cell morphology were observed microscopically as described 
previously [7]. Isolation of the DNA was performed with a commercial DNA extraction kit (GenElute ${ }^{\mathrm{TM}}$ Plant Genomic DNA Kit, Sigma) after disruption of cells by an $1 \mathrm{~min}$ bead-beating step with $1 \mathrm{~g}$ of $0.1 \varnothing$ Zirconia beads at maximum speed.

Multiple sequence alignment and analysis of the data were performed using the software package Molecular Evolutionary Genetics Analysis (MEGA) version 4 [17]. Genetic distance calculations (distance options according to the Kimura-2 model, 17) and clustering with the neighbor-joining method (Fig. 1) was performed by using bootstrap values based on 1000 replications. The $16 \mathrm{~S}$ rRNA gene sequence of strain $02-\mathrm{St}-019 / 1^{\mathrm{T}}$ was a continuous stretch of $1348 \mathrm{bp}$ and was deposited in EMBL, under the accession number FM992368.

Sequence similarity calculations after a neighborjoining analysis showed, that the most similar sequences to that of strain $02-\mathrm{St}-019 / 1^{\mathrm{T}}$ belonged to Kytococcus schroeteri DSM $13884^{\mathrm{T}}(98.6 \%)$ and $K$. sedentarius DSM $20547^{\mathrm{T}}(98.3 \%)$.

Bacterial biomass for chemotaxonomic investigations of the isolates was prepared by cultivating strain $02-\mathrm{St}$ $019 / 1$ for $2448 \mathrm{~h}$ in shake flasks in liquid organic medium M79 at $180 \mathrm{rpm}$ at $28^{\circ} \mathrm{C}$, except for fatty acid analyses cells were grown on tryptic soy agar (TS agar,
[7]). Standard HPLC and TLC procedures were used to determine whole-organism sugars $[2,12]$, quinone system [4] and polar lipids [3,10]. Fatty acid analysis was performed according to Kämpfer \& Kroppenstedt [6]. Peptidoglycan was obtained after disintegration of cells with glass beads in a Vibrogen cell mill (Johanna Otto GmbH, D-72408 Bodelshausen, Germany) and subsequent trypsin digestion [15]. The elucidation of the peptidoglycan structure was carried out as described elsewhere $[13,14]$ with the modification that TLC on cellulose was applied instead of paper chromatography. Quantitative analysis of amino acids was performed after derivatization by gas chromatography and gas chromatography/mass spectrometry (320-MS Quadrupole GC/MS, Varian) [5,9].

The following amino acids were detected in the total hydrolysate of the peptidoglycan $\left(4 \mathrm{~N} \mathrm{HCl}, 100^{\circ} \mathrm{C}\right.$, $16 \mathrm{~h})$ : alanine:glycine:glutamic acid:lysine $=1.6: 0.1$ : 2.5:1.0 (molar ratio). Dinitrophenylation according to Schleifer [13] revealed glutamic acid as $N$-terminus of the interpeptide bridge. The partial hydrolysate $\left(4 \mathrm{~N} \mathrm{HCl}, 100^{\circ} \mathrm{C}, 0.75 \mathrm{~h}\right.$ ) of the peptidoglycan contained in addition to the amino acids the peptides L-Ala-D-Glu and L-Lys-D-Ala. The traces of glycine may result from minor amounts of contaminating proteins in the

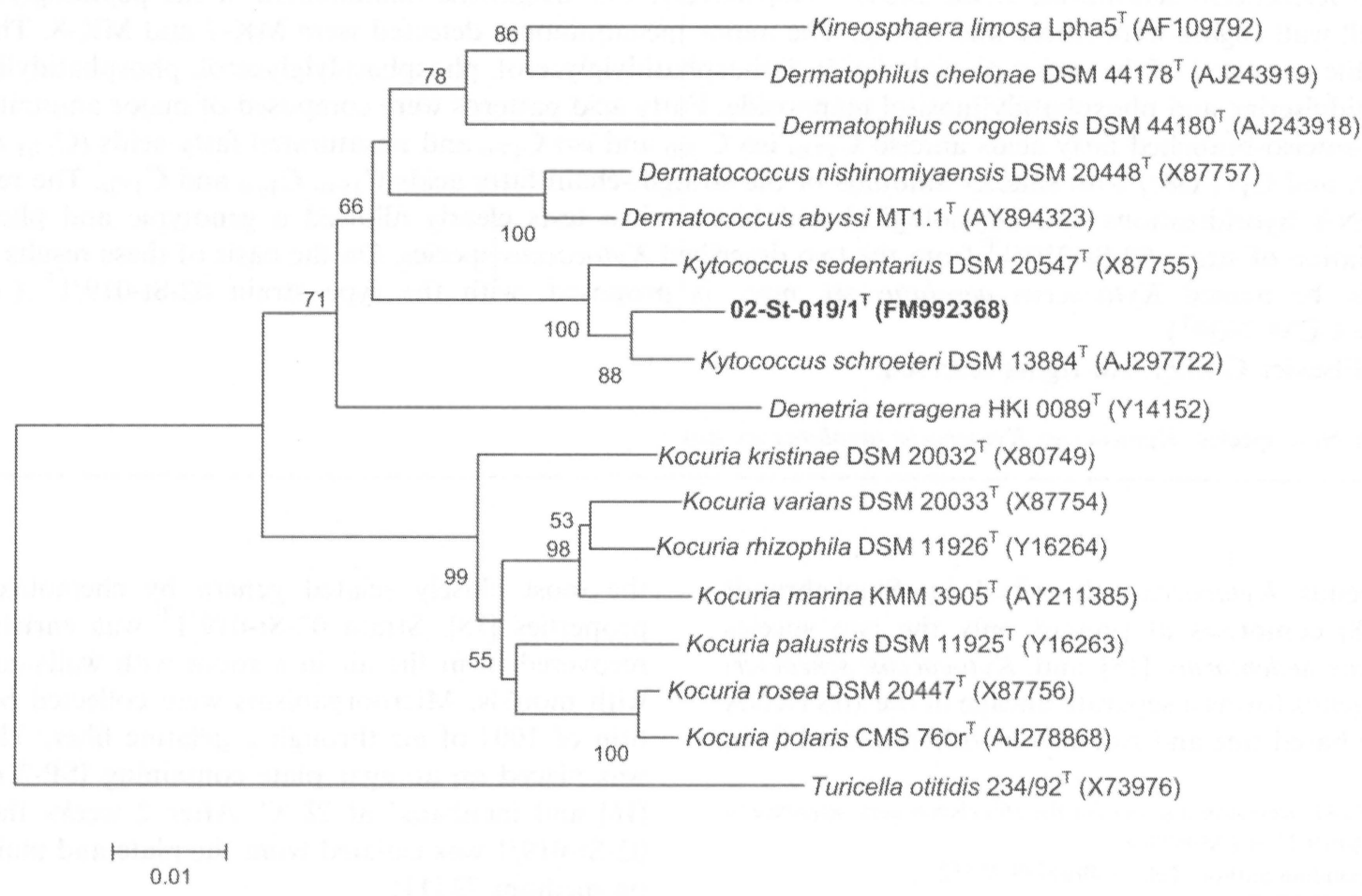

Fig. 1. Phylogenetic analysis based on 16S rRNA gene sequences available from the European Molecular Biology Laboratory data library (accession numbers are given in brackets). Multiple alignement, distances (distance options according to the Kimura-2 model) and clustering with the neighbor-joining method were performed by using the software packages Molecular Evolutionary Genetics Analysis (MEGA) version 4 (Tamura et al. [17]). Bootstrap values based on 1000 replications are listed as percentages at the branching points. 
peptidoglycan preparations. From these data the peptidoglycan type A $4 \alpha$ L-Lys-D-Glu-D-Glu (A11.43 according to http://www.dsmz.de/microorganisms/ main.php?content_id $=35$ ) can be concluded which is in agreement with the affiliation of strain $02-\mathrm{St}-019 / 1$ to the genus Kytococcus.

The whole-organism hydrolysate contained the sugars ribose and xylose. In difference to the already described Kytococcus species strain $02-\mathrm{St}-019 / 1^{\mathrm{T}}$ exhibited a quinone system with the predominant menaquinones MK-7 $(64 \%)$, MK-8 $(28 \%)$ and minor amounts of MK-6 (3\%) whereas the isoprenoid quinones of $K$ schroeteri were represented by approximately equivalent amounts of MK-8, MK-7 and minor amounts of MK-9 (peak area ratio 43:36:1, [1]). The polar lipid profile was rather complex consisting of eight components (Fig. 2). In accordance with the genus description major lipids were diphosphatidylglycerol, phosphatidylglycerol and phosphatidylinositol. Additionally four unknown lipids - two phospholipids, one glycolipid and one ninhydrin-positive lipid, phosphatidylserine and phosphatidylinositol mannoside were detected as well. Although unknown lipids were found in $K$. sedentarius, phosphatidylserine and phosphatedylinositol mannoside were not detected.

The fatty acid profile of strain $02-\mathrm{St}-019 / 1^{\mathrm{T}}$ was similar to those of the other closely related species $K$. schroeteri and $K$. sedentarius, but more similar to that of $K$ schroeteri [1]. The fatty acid profile was dominated by iso- and anteiso-branched fatty acids anteiso $\mathrm{C}_{17: 0}$, iso $\mathrm{C}_{15: 0}$ and iso $\mathrm{C}_{17: 0}$. and unsaturated

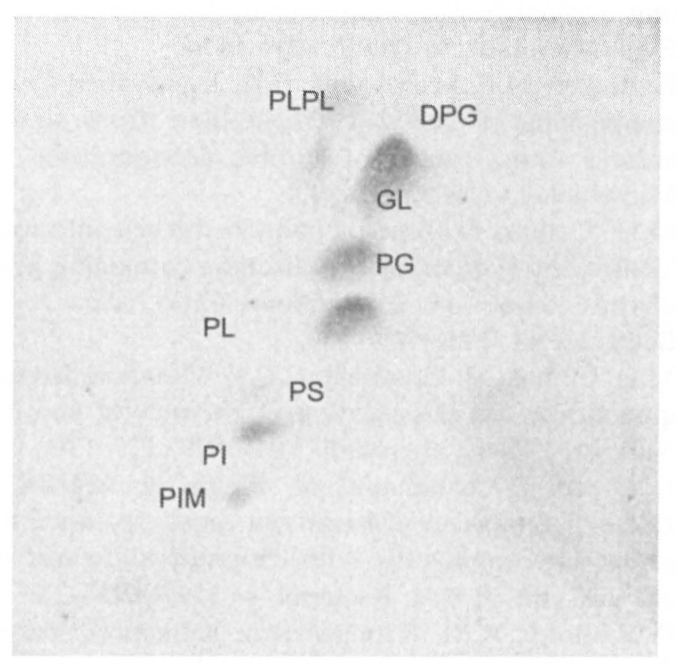

Fig. 2. Two-dimensional TLC of polar lipid extracts from strain $02-\mathrm{Be}-019^{\mathrm{T}}$, stained with molybdatophosphoric acid. DPG, diphosphatidylglycerol; PG, phosphatidylglycerol; PI, phosphatidylinositol; PS, phosphatidylserine; PIM, phosphatidylinositol mannoside; GL, unknown glycolipid; PL, unknown phospholipid. fatty acids $\left(\mathrm{C}_{17: 1} \omega 8 \mathrm{c}\right.$, iso $\mathrm{C}_{17: 1} \omega 9 \mathrm{c}$, and $\left.\mathrm{C}_{17: 1} \omega 8 \mathrm{c}\right)$, which were also present in $K$ schroeteri and $K$. sedentarius (Table 1 and [1]).

Results of the comparative physiological characterization using always identical test conditions are given in Table 2 and the species description were obtained with methods as described previously [8]. Only few carbon sources were utilized by strain $02-\mathrm{St}-019 / 1^{\mathrm{T}}$.

DNA-DNA hybridisation experiments were performed with $02-\mathrm{St}-019 / \mathrm{I}^{\mathrm{T}}$ and the type strains of $K$. schroeteri DSM $13884^{\mathrm{T}}$, and $K$. sedentarius DSM $20547^{\mathrm{T}}$ using the method described by Ziemke et al. [19], with minor variation in the nick translation step, where $2 \mu \mathrm{g}$ of DNA was labelled during a $3 \mathrm{~h}$ incubation at $15^{\circ} \mathrm{C}$. Strain $02-\mathrm{St}-019 / 1^{\mathrm{T}}$ showed a relatively low DNA-DNA similarity to $K$. schroeteri DSM $13884^{\mathrm{T}}$ of $40 \%$, (reciprocal $45 \%$ ), and to $K$. sedentarius DSM $20547^{\mathrm{T}} 20.8 \%$ (reciprocal $23.6 \%$ ). The observed physiological and chemotaxonomic differences between these type strains (Tables 1 and 2) clearly indicate that strain $02-\mathrm{St}-019 / 1^{\mathrm{T}}$ represents a novel species for which the name Kytococcus aerolatus sp. nov is proposed.

Table 1. Fatty acid composition of strains $1,02-\mathrm{St}-019 / 1^{\mathrm{T}} ; 2$, K. sedentarius DSM $20547^{\mathrm{T}} ; 3$, K. schroeteri DSM $13884^{\mathrm{T}}$.

\begin{tabular}{lrrr}
\hline & \multicolumn{1}{c}{$\mathbf{2}$} & \multicolumn{1}{c}{$\mathbf{3}$} \\
\hline Saturated & & & \\
C15:0 & 3.9 & 2.3 & 1.1 \\
C16:0 & 4.5 & 1.0 & 0.7 \\
C17:0 & 3.0 & 9.6 & \\
Unsaturated & & & \\
C15:1 $06 \mathrm{c}$ & 6.6 & 1.9 & 0.7 \\
Iso C17:1 $09 \mathrm{c}$ & 12.1 & 17.1 & 23.7 \\
Anteiso C17:1 $\omega 9 \mathrm{c}$ & 3.2 & 3.3 & 3.3 \\
C17:1 $\omega 8 \mathrm{c}$ & 11.2 & 16.4 & 0.9 \\
C17:1 $\omega 6 \mathrm{c}$ & 1.9 & 1.8 & \\
Branched-chain fatty acid & & & \\
iso-C11:0 & & & \\
iso-C13:0 & & & 0.5 \\
iso-C15:0 & 4.8 & 2.7 & 29.7 \\
anteiso-C15:0 & 1.7 & 2.5 & 4.4 \\
iso-C16:0 & 3.5 & 2.9 & 3.0 \\
iso-C17:0 & 7.3 & 14.5 & 16.7 \\
anteiso-C17:0 & 18.8 & 22.3 & 10.6 \\
10-methyl C17:0 & & 0.6 & \\
C18:1 Iso H & & & 1.0 \\
Summed features 1* & & & $\mathbf{1 . 0}$ \\
Summed features 3* & $\mathbf{1 7 . 5}$ & $\mathbf{2 . 1}$ & $\mathbf{1 . 0}$ \\
Summed features 4* & & & $\mathbf{0 . 6}$ \\
\hline & & & \\
\hline
\end{tabular}

Data for all strains from this study. All strains were grown on TS agar for $48 \mathrm{~h}$ at $28^{\circ} \mathrm{C}$.

${ }^{*}$ Summed feature 1: iso-C15:1 $\mathrm{H}$ and/or C13:0 3-OH.Summed feature 3: $\mathrm{Cl} 16: 1 \omega 7 \mathrm{c}$ and/or iso-C15:0 2-OH.Summed feature 4: iso-C17:1 I and/or anteiso-C17:1 B. 
Table 2. Physiological test results for strains 1, 02-St $-019 /^{\mathrm{T}}$; $2, K$. sedentarius DSM $20547^{\mathrm{T}} ; 3, K$. schroeteri DSM $13884^{\mathrm{T}}$.

\begin{tabular}{|c|c|c|c|}
\hline Tests $\$$ & 1 & 2 & 3 \\
\hline \multicolumn{4}{|l|}{ Hydrolysis of: } \\
\hline pNP- $\alpha$-D-glucopyranoside & - & + & - \\
\hline Bis-pNP-phosphate & - & + & + \\
\hline pNP-phenyl-phosphonate & - & + & + \\
\hline pNP-phosphoryl-choline & - & + & - \\
\hline L-Alanine-pNA & - & $(+)$ & + \\
\hline \multicolumn{4}{|l|}{ Assimilation of: } \\
\hline D-Fructose & - & $(+)$ & - \\
\hline D-Glucose & - & + & + \\
\hline D-Mannose & - & $(+)$ & - \\
\hline D-Maltose & - & + & $(+$ \\
\hline Sucrose & - & + & $(+)$ \\
\hline D-Trehalose & - & + & + \\
\hline Propionate & - & $(+)$ & + \\
\hline Glutarate & - & - & + \\
\hline DL-3-Hydroxybutyrate & - & - & + \\
\hline Itaconate & - & - & - \\
\hline L-Malate & - & $(+)$ & - \\
\hline Oxoglutarate & - & - & + \\
\hline L-Aspartate & - & + & + \\
\hline L-Histidine & - & + & - \\
\hline L-Leucine & - & - & + \\
\hline L-Ornithine & - & - & + \\
\hline L-Phenylalanine & - & - & - \\
\hline L-Proline & - & + & + \\
\hline
\end{tabular}

Data for all strains from this study. None of the strains produced acid from the following carbohydrates: Glucose, Lactose, Sucrose, DMannitol, Dulcitol, Salicin, Adonitol, Inositol, Sorbitol, L-arabinose, Raffinose, Rhamnose, Maltose, D-Xylose, Trehalose, Cellobiose, Methyl-D-glucoside, Erythritol, Melibiose, D-Arabitol, D-Mannose. The following chromogenic substrates were not hydrolysed: Esculin, oNP-B-D-galactopyranoside, pNP-B-D-glucuronide, pNP-B-D-glucopyranoside, pNP-B-D-xylopyranoside, 2-Deoxythymidine-5'-pNPphosphate, L-Glutamate-gamma-3-carboxy-pNA, L-Proline-pNA. None of the strains utilized the following compounds as sole sources of carbon: N-Acetyl-D-galactosamine, N-Acetyl-D-glucosamine, LArabinose, p-Arbutin, D-Cellobiose, D-Galactose, Gluconate, alphaD-Melibiose, L-Rhamnose, D-Ribose, Salicin, D-Xylose, Adonitol, iInositol, Maltitol, D-Mannitol, D-Sorbitol, Putrescine, cis-Aconitate, trans-Aconitate, Adipate, 4-Aminobutyrate, Azelate, Citrate, Mesaconate, Suberate, L-Alanine, B-Alanine, L-phenylalanine, L-Serine, LTryptophane, 3-Hydroxybenzoate, 4-Hydroxybenzoate and Phenylacetate. All strains utilized acetate, fumarate, DL-lactate and pyruvate (for strain $02-\mathrm{St}-019 / 1^{\mathrm{T}}$ only weak positive results were observed).

\section{Description of Kytococcus aerolatus sp. nov.}

Kytococcus aerolatus (ae.ro.la'tus. Gr. n. aer air; L. part. adj. latus carried; N.L. masc. part. adj. aerolatus airborne).

Coccoid cells, about $1.3 \mu \mathrm{m}$ in diameter. Grampositive, oxidase-positive, catalase-positive showing an oxidative metabolism. Beige pigmented colonies are formed on nutrient agar. Good growth occurs after $24 \mathrm{~h}$ of incubation on tryptone soy agar, R2A agar and nutrient agar at $25-30^{\circ} \mathrm{C}$. The peptidoglycan type is A4 $\alpha$ (L-Lys-D-Glu-D-Glu). The quinone system of $02-\mathrm{St}-019 / 1^{\mathrm{T}}$ is composed of MK-7 and MK-8. The polar lipid profile consists of the major lipids diphosphatidylglycerol, phosphatidylglycerol, phosphatidylinositol, phosphatidylserine and phosphatedylinositol mannoside. Major fatty acids are iso- and anteisobranched fatty acids anteiso $\mathrm{C}_{17: 0}$, iso $\mathrm{C}_{15: 0}$ and iso $\mathrm{C}_{17: 0}$ and unsaturated fatty acids $\left(\mathrm{C}_{17: 1} \omega 8 \mathrm{c}\right.$, iso $\mathrm{C}_{17: 1} \omega 9 \mathrm{c}$, and $\left.\mathrm{C}_{17: 1} \omega 8 \mathrm{c}\right)$ with smaller amounts of the straight-chain fatty acids $C_{15: 0}, \quad C_{16: 0}$ and $C_{17: 0}$. Carbon source utilizations (including differentiating characters using always identical conditions) are indicated in Table 1.

Isolated in Stuttgart, Germany, sampled from the air in a house with walls colonized with moulds. Type strain is $02-\mathrm{St}-019 / 1^{\mathrm{T}}\left(=\mathrm{DSM} 22179^{\mathrm{T}}=\mathrm{CCM} 7639^{\mathrm{T}}\right)$.

\section{Acknowledgement}

We are grateful to Carmen Schult, Gundula Will and Anika Wasner (DSMZ) for excellent technical assistance and Jean Euzéby for support with the nomenclature. The study was supported in part by the Federal Environment Agency (Umweltbundesamt), Grant no. FKZ 20562236.

\section{References}

[1] K. Becker, P. Schumann, J. Wüllenweber, M. Schulte, H.P. Weil, E. Stackebrandt, C, von Eiff, Kytococcus schroeteri sp. nov., a novel Gram-positive actinobacterium isolated from a human clinical source, Int. J. Syst. Evol. Microbiol. 52 (2002) 1609-1614.

[2] B. Becker, M.P. Lechevalier, H.A. Lechevalier, Chemical composition of cell-wall preparations from strains of various form - genera of aerobic actinomycetes, Appl. Microbiol. 13 (1965) 236-243.

[3] M.D. Collins, D. Jones, Lipids in the classification and identification of coryneform bacteria containing peptidoglycans based on 2,4-diaminobutyric acid, J. Appl. Bacteriol. 48 (1980) 459-470.

[4] M.D. Collins, M. Goodfellow, D.E. Minnikin, Isoprenoid quinones in the classification of coryneform and related bacteria, J. Gen. Microbiol. 110 (1977) 127-136.

[5] I. Groth, P. Schumann, N. Weiss, K. Martin, F.A. Rainey, Agrococcus jenensis gen. nov., sp. nov., a new genus of actinomycetes with diaminobutyric acid in the cell wall, Int. J. Syst. Bacteriol. 46 (1996) 234-239.

[6] P. Kämpfer, R.M. Kroppenstedt, Numerical analysis of fatty acid patterns of coryneform bacteria and related taxa, Can. J. Microbiol. 42 (1996) 989-1005.

[7] P. Kämpfer, R.M. Kroppenstedt, Pseudonocardia benzenivorans sp. nov, Int. J. Syst. Evol. Microbiol. 54 (2004) 749-751.

[8] P. Kämpfer, M. Steiof, W. Dott, Microbiological characterisation of a fuel - oil contaminated site including 
numerical identification of heterotrophic water and soil bacteria, Microb. Ecol. 21 (1991) 227-251.

[9] S.L. MacKenzie, Gas chromatographic analysis of amino acids as the N-heptafluorobutyryl isobutyl esters, J. Assoc. Off. Anal. Chem. 70 (1987) 151-160.

[10] D.E. Minnikin, M.D. Collins, M. Goodfellow, Fatty acid and polar lipid composition in the classification of Cellulomonas, Oerskovia and related taxa, J. Appl. Bacteriol. 47 (1979) 87-95.

[11] H. Prauser, R. Falta, Phagensensibilität, Zellwand-Zusammensetzung und Taxonomie von Actinomyceten, $Z$. Allg. Mikrobiol. 8 (1968) 3946.

[12] G.S. Saddler, P. Tavecchia, S. Lociuro, M. Zanol, L. Colombo, E. Selva, Analysis of madurose and other actinomycete whole cell sugars by gas chromatography, $J$. Microbiol. Methods 14 (1991) 185-191.

[13] K.H. Schleifer, Analysis of the chemical composition and primary structure of murein, Methods Microbiol. 18 (1985) 123-156.

[14] K.H. Schleifer, O. Kandler, Peptidoglycan types of bacterial cell walls and their taxonomic implications, Bacteriol. Rev. 36 (1972) 407-477.
[15] K.H. Schleifer, P.H. Seidl, Chemical composition and structure of murein, in: M. Goodfellow, D.E. Minnikin (Eds.), Chemical methods in bacterial systematics, Academic Press, London, 1985, pp. 201-215.

[16] E.B. Shirling, D. Gottlieb, Methods for the characterization of Streptomyces species, Int. J. Syst. Bacteriol. 16 (1966) 313-340.

[17] K. Tamura, J. Dudley, M. Nei, S. Kumar, MEGA4: Molecular Evolutionary Genetics Analysis (MEGA) software version 4.0, Mol. Biol. Evol. 24 (2007) 1596-1599.

[18] E. Stackebrandt, C. Koch, O. Gvozdiak, P. Schumann, Taxonomic dissection of the genus Micrococcus: Kocuria gen. nov., Nesterenkonia gen. nov., Kytococcus gen. nov., Dermacoccus gen. nov., and Micrococcus Cohn 1872 gen. emend, Int. J. Syst. Bacteriol. 45 (1995) 682-692.

[19] F. Ziemke, M.G. Höfle, J. Lalucat, R. Rosselló-Mora, Reclassification of Shewanella putrefaciens Owen's genomic group II as Shewanella baltica sp. nov., Int. J. Syst. Bacteriol. 48 (1998) 179-186. 